\title{
Thermal Inactivation of Phytophthora nicotianae
}

\author{
L. Coelho, D. J. Mitchell, and D. O. Chellemi
}

First author: Faculdade de Ciencias Agrarias, UNESP, Jaboticabal, SP 14870-000, Brazil; second author: Department of Plant Pathology, University of Florida, Gainesville 32611; and third author: U.S. Department of Agriculture, Agricultural Research Service, 2199 South Rock Road, Fort Pierce, FL 34945.

Accepted for publication 16 May 2000.

\begin{abstract}
Coelho, L., Mitchell, D. J., and Chellemi, D. O. 2000. Thermal inactivation of Phytophthora nicotianae. Phytopathology 90:1089-1097.

Phytophthora nicotianae was added to pasteurized soil at the rate of 500 laboratory-produced chlamydospores per gram of soil and exposed to temperatures ranging from 35 to $53^{\circ} \mathrm{C}$ for 20 days. The time required to reduce soil populations to residual levels ( 0.2 propagule per gram of soil or less) decreased with increasing temperatures. Addition of cabbage residue to the soil reduced the time required to inactivate chlamydo-
\end{abstract}

ABSTRACT spores. Temperature regimes were established to simulate daily temperature changes observed in the field, with a high temperature of $47^{\circ} \mathrm{C}$ for $3 \mathrm{~h} / \mathrm{day}$, and were good estimators of the efficacy of soil solarization for the control of $P$. nicotianae in soil. Cabbage amendment reduced the time required to inactivate chlamydospores of $P$. nicotianae and its effect was more pronounced at lower temperature regimes.

Additional keywords: Brassica oleracea, intermittent heat, nonchemical control, organic amendment.
Studies of thermal inactivation of pathogens can yield important information on survival of specific types of propagules, and when simulating field conditions, can serve as the basis for estimation of the time needed for soil solarization to effectively control soilborne plant pathogens $(2,18,21)$. Juarez-Palacios et al. (13) found that determination of the heat sensitivity of isolates of Phytophthora spp. in the laboratory closely reflected their inactivation in solarized soil and indicated the possible use of soil solarization for management of those pathogens. These authors found that an isolate of $P$. megasperma tolerant to high temperature survived exposure for $30 \mathrm{~min}$ at $45^{\circ} \mathrm{C}$ in a heat sensitivity study; however, $P$. cinnamomi and a low-temperature isolate of $P$. megasperma did not survive exposure at $45^{\circ} \mathrm{C}$ for $20 \mathrm{~min}$. Bollen (5) noted that different types of propagules have different sensitivities to heat. Oospores of $P$. capsici were more thermotolerant than mycelium from either mating type of this pathogen; oospores survived at $50^{\circ} \mathrm{C}$ for $30 \mathrm{~min}$, but mycelium was eliminated at 42.5 to $45^{\circ} \mathrm{C}$ for $30 \mathrm{~min}$.

The use of heat to inactivate spores of microorganisms in diverse media began as early as 1920 (4). Soon after that the advantages of the logarithmic transformation for the analysis of the data were realized $(3,4,24)$. The logarithmic transformation indicates that a constant proportion of the spore population is killed per unit of time and serves the purpose of linearizing the data. Simple linear regressions could be used for the analysis of the effect of time on the survival of spores at each temperature employed; coefficients for lethal dosages $\left(\mathrm{LD}_{50}\right.$ or $\left.\mathrm{LD}_{90}\right)$ could be interpolated from the data. Pullman et al. (21) demonstrated that the logarithmic relationship between time and temperature on the survival of four soilborne plant pathogens was maintained at temperatures below $50^{\circ} \mathrm{C}$. The exposure time required to reduce the

Corresponding author: L. Coelho; E-mail address: lisias@fcav.unesp.br

Florida Experiment Station Journal Series R-06923.

Publication no. P-2000-0803-03R

(C) 2000 The American Phytopathological Society population by $90 \%\left(\mathrm{LD}_{90}\right)$ for oospores of Pythium ultimum increased as the temperature decreased from 50 to $37^{\circ} \mathrm{C}$. The study was performed with soil moisture adjusted to field capacity and closely reflects common temperature profiles observed in soil solarization tests.

One of the first attempts to control plant pathogens by exposure to intermittent heat was that of Grooshevoy et al. (12). The authors demonstrated that exposing chlamydospores of Thielaviopsis basicola or sclerotia of a Rhizoctonia sp. or Sclerotinia sclerotiorum for $3 \mathrm{~h} /$ day at $45^{\circ} \mathrm{C}$ for 5 days was sufficient to prevent germination of the propagules. However, in that study no attempts were made to simulate diurnal temperature fluctuations. Porter (19) evaluated the effect of intermittent heat on the control of sclerotia of $S$. sclerotiorum in soil and found continuous heat more effective than intermittent heat for reducing the number of viable sclerotia when the infested soil was heated for $6 \mathrm{~h} /$ day over 14 days to temperatures ranging from 30 to $45^{\circ} \mathrm{C}$. In a similar study with several pathogens, Porter and Merriman (20) observed that the tolerance to heat exposure varied among different genera of plant pathogens; however, the type of fungal propagules used for this study was not determined. Due to the labor-intensive nature of these studies and the demand for equipment, very little research has been done on the quantitative relationship of intermittent heat to the inactivation of spores of plant pathogens.

Studies of thermal inactivation can be complemented to simulate other conditions in the field, such as the addition of organic amendments to the soil prior to solarization $(10,11,22,23)$. Cabbage residue associated with solarization was used successfully to control cabbage yellows caused by Fusarium oxysporum f. sp. conglutinans $(22,23)$. The addition of cabbage alone was only partially effective for the control of cabbage yellows, but when cabbage residue was heated in solarization there was significant control of the pathogen.

Phytophthora nicotianae (Breda de Haan; synonym, P. parasitica Dastur) is an important soilborne plant pathogen with a wide host range (1). Diseases caused by this pathogen, such as seedling damping off, root rot, blight, and fruit rot have limited the production of several important crops $(9,16)$. P. nicotianae can survive in soil for long periods of time in the absence of its host 
plants and when weather conditions are not favorable for disease initiation and development (9). Thus, the main strategies used by growers to reduce losses due to this pathogen, especially at the early stages of plant development, are preplant soil fumigation with methyl bromide and postplant application of fungicides. Although soil solarization has been used to reduce populations of $P$. nicotianae, disease management was not always observed $(6,8)$. Therefore, thermal inactivation studies could indicate which adjustments are needed for the efficient use of solarization as an alternative for the control of this important soilborne plant pathogen.

Due to the demands on time and equipment, thermal inactivation studies very seldom explore extensive combinations of both time and temperature ranges. Thus, the full benefits that can be derived from such experiments are often not realized. The objectives of this study are to evaluate the effects of constant and pulsing temperatures and cabbage amendment on the survival of $P$. nicotianae.

\section{MATERIALS AND METHODS}

Production of chlamydospore inoculum. Chlamydospores of $P$. nicotianae were produced in V8-juice broth according to the procedures outlined by Mitchell and Kannwischer-Mitchell (17). The isolate of $P$. nicotianae used (Pn21) was originally isolated from periwinkle in South Florida and was maintained in the collection of Phytophthora spp. of the Plant Pathology Department at the University of Florida (Gainesville). The total number of chlamydospores in the suspension was estimated with a hemacytometer, and the suspension was used immediately to infest pasteurized soil. Soil was collected from a field previously cropped to tomato and tobacco in Decatur County, Georgia. Inoculum was adjusted to a density of 500 chlamydospores per $g$ of soil. Thirty grams of infested soil was dispensed in a borosilicate glass test tube $(25 \times 150 \mathrm{~mm})$ that was loosely closed with a plastic cap to allow exchange of air.

Effect of constant temperature on the inactivation of chlamydospores. A set of test tubes was placed in each of eight water baths held at the following constant temperatures with circulation heaters: $25,35,38,41,44,47,50$, and $53 \pm 0.02^{\circ} \mathrm{C}$. The time of exposure at each temperature was $5,10,15,30,45,60,75$, 90,105 , and $120 \mathrm{~min}$ or $2,4,8,12,16,20,24,48,96,192,288$, 384 , and $480 \mathrm{~h}$. Three tubes were removed at each time interval and a portion of the soil $(15 \mathrm{~g})$ from each tube was diluted with soft agar (2.5 g of Difco agar per liter of deionized water) and plated on a medium selective for pythiacious fungi (PARP; 17). The soil overlay was removed from the plates after $48 \mathrm{~h}$ by gently washing the agar surface with tap water. The total number of colonies that formed on PARP after $72 \mathrm{~h}$ of incubation was recorded as an estimate of the number of chlamydospores that survived the heat treatment. The remaining $15 \mathrm{~g}$ of soil was baited with three 3-day-old 'Solar Set' tomato seedlings and incubated in a growth chamber at $27^{\circ} \mathrm{C}$ for 3 days. The seedlings were rinsed twice in sterile water, blotted dry, and plated on PARP to evaluate the colonization of tissues by $P$. nicotianae. The number of seedlings with fungal colonization was recorded. The experiment with exposure times ranging from 5 to $120 \mathrm{~min}$ was repeated once, and the experiment with exposure times ranging from 2 to $480 \mathrm{~h}$ was repeated twice.

The effect of cabbage amendments on the thermal inactivation of chlamydospores. In order to determine the effect of cabbage amendments on the inactivation of chlamydospores of $P$. nicotianae, experiments similar to those described previously were conducted with temperatures at 35,38 , and $41 \pm 0.02^{\circ} \mathrm{C}$, and time periods of $2,4,8,12,16,20,24,48,96,192,288,384$, and $480 \mathrm{~h}$. Leaves of cabbage (Brassica oleracea var. capitata) were air dried in a greenhouse and ground in a Wiley mill with a 20mesh screen. Pasteurized soil was amended with dry, ground cabbage leaves at $0,0.125,0.25$, and $0.5 \%$ (wt/wt) and infested with 500 chlamydospores per $\mathrm{g}$ of soil. Thirty grams of amended soil infested with chlamydospores was dispensed in a borosilicate glass test tube $(25 \times 150 \mathrm{~mm})$. The tube was sealed with a gasimpermeable plastic film (Bromotec film; Lawson Mardon Packaging, Workington, Cumbria, U.K.), and a plastic cap was placed over the tube to reduce the exchange of air and trap the volatiles released by heating the cabbage-amended soil. The test tubes were placed in water baths at constant temperatures with circulation heaters, three tubes were removed at each time interval, and the soil was processed as previously described.

The effect of cycling temperatures and cabbage amendments on the thermal inactivation of chlamydospores. A critical analysis of the effects of daily temperature fluctuation, as observed during soil solarization, on the survival of the pathogen was performed. Based on an analysis of published data from North Florida (6), two temperatures, representative of average temperature profiles at 10 and $25 \mathrm{~cm}$ of soil depth, and duration of daily exposure were selected. The daily regimes selected were $5 \mathrm{~h}$ at $41^{\circ} \mathrm{C}$ and $8 \mathrm{~h}$ at $35^{\circ} \mathrm{C}$, each coupled with a baseline temperature of $25^{\circ} \mathrm{C}$ for the rest of the day. These temperatures were maintained with circulation heaters in water baths. After preliminary tests indicated a high percentage of the spores survived the heat treatment, a third temperature at $44^{\circ} \mathrm{C}$ for $1.5 \mathrm{~h}$ /day was added. The duration of the daily exposure at $44^{\circ} \mathrm{C}$ was based on the results of previous tests with constant temperature and on the analysis of temperature profiles from field experiments in 1994 (6).

Pasteurized and infested soil was adjusted to a final moisture of $6 \%$ with sterile water. Half of the infested soil was amended with dry, ground cabbage leaves at $0.125 \%$ (wt/wt). This concentration of cabbage was selected because no phytotoxic effects were observed on tomato seedlings and it matched the amount of cabbage residue applied in the solarization tests in North Florida (7). Thirty grams of soil was dispensed in a test tube that was sealed with a piece of the gas-impermeable plastic film and a plastic cap.

The test tubes were placed in water baths at $25^{\circ} \mathrm{C}$ until the temperature of the soil and the water were equilibrated, and cycling was initiated. Temperatures were monitored with thermocouples connected to a datalogger (CR10; Campbell Scientific Inc., Logan, UT). Three tubes were removed after 1, 2, and 3 days and every 3 days thereafter for a period of 24 days. Part of the soil $(15 \mathrm{~g})$ was diluted with soft agar and plated on PARP within $24 \mathrm{~h}$, as previously described. The number of colonies was recorded. The remaining soil was used in a plant disease assay.

At the end of the thermocycling experiment, all remaining samples were transferred to tripour plastic beakers $(50 \mathrm{ml})$, and one 1-month-old tomato seedling was transplanted in the soil in each beaker. Vermiculite $(10 \mathrm{ml})$ was poured on the top of the soil to prevent the roots from desiccating. All plants were kept in a growth chamber at $27^{\circ} \mathrm{C}$ for 30 days. As plants died, the root systems were rinsed in water, surface disinfested for $30 \mathrm{~s}$ in $70 \%$ ethanol, rinsed twice in sterile water, and plated on PARP. At the end of the experiment, all plants were removed and the root systems were plated on PARP for determination of infection.

The use of average temperatures achieved during soil solarization for the temperature cycling experiments were not sufficient to completely inactivate chlamydospores of $P$. nicotianae; therefore, an additional experiment was conducted with temperature regimes achieved during an optimum solarization day at the North Florida Research and Education Center at Quincy in 1995 (7). Temperature regimes were at $47^{\circ} \mathrm{C}$ for $3 \mathrm{~h} /$ day, $44^{\circ} \mathrm{C}$ for $5 \mathrm{~h} /$ day, and $35^{\circ} \mathrm{C}$ for $8 \mathrm{~h} /$ day. Throughout this experiment, a baseline temperature of $25^{\circ} \mathrm{C}$ was maintained for the remainder of the day. The duration of each experiment was 15 days, and the experiment was repeated once.

The procedures for production of chlamydospores, treatment of soil, and estimation of soil populations of $P$. nicotianae were the same as described previously. At the end of the temperature cycling experiments, a plant disease assay was performed for 4 weeks with 1-month-old tomato seedlings, as described previously. 
Statistical analysis. The results of each experiment were analyzed individually. When statistical analysis of the residuals indicated that the results could be pooled due to the lack of variation, a final analysis was done with the pooled data.

The response surfaces were analyzed according to the procedure PROC NLIN (SAS Institute, Cary, NC; release 6.11). Modeling was done with temperatures above $38^{\circ} \mathrm{C}$ to better establish end points of the surfaces. Survival data were transformed using $\ln (\mathrm{ppg}+1)$ prior to analysis. The analyses of the effect of temperature cycling and cabbage amendment on the survival of chlamydospores of $P$. nicotianae were performed using Statgraphics Plus (Version 2.1, Manugistics Inc., Rockville, MD) for the convenience of comparing several linearization models at once.

\section{RESULTS}

Effect of constant temperature on the inactivation of chlamydospores. $P$. nicotianae was consistently recovered throughout the 2-h experiment at temperatures below $47^{\circ} \mathrm{C}$ (Fig. 1A). At $44^{\circ} \mathrm{C}$, a sharp decrease in recovery was observed after $30 \mathrm{~min}$, but $10 \%$ of the initial population of 500 propagules per gram (ppg) of soil survived to the end of the experiment. After 75 min of heat treatment at $47^{\circ} \mathrm{C}$, population levels dropped below $1 \mathrm{ppg}$ of soil, and after $2 \mathrm{~h}$ populations declined to levels undetectable by the procedure used to quantify the inoculum in the soil. At 50 and $53^{\circ} \mathrm{C}$ populations were very low after only $5 \mathrm{~min}$ of exposure.

The decline in survival of the chlamydospores of $P$. nicotianae in soil exposed to constant heat above $38^{\circ} \mathrm{C}$ for 5 to 120 min was determined by

$$
\ln (\mathrm{ppg}+1)=\left(6.2-0.00108 \times \text { time }^{2}\right) e^{-0.02208 \times \text { temperature }}
$$

Model selection was based on comparison of observed vs predicted values, residual error vs time, residual error vs temperature, and on the coefficient of determination $\left(R_{\text {adj }}^{2}=0.8234\right)$.

The use of tomato seedlings as bait for the detection of survival of $P$. nicotianae indicated that survival was affected by the heat treatment only after $90 \%$ of the initial population of chlamydospores had been inactivated, which occurred generally only after exposure to $47^{\circ} \mathrm{C}$ or higher (Fig. 1B). Detection of survival by the seedlings was not as sensitive as detection by the soil dilution procedure. For example, at $53^{\circ} \mathrm{C}$ no seedlings were infected after heat treatment following the 3-day incubation period (Fig. $1 \mathrm{~B})$; in contrast, the soil dilution procedure indicated that $0.1 \mathrm{ppg}$ of soil was still alive after $15 \mathrm{~min}$ of treatment (Fig. 1A).

Survival of chlamydospores exposed to $35^{\circ} \mathrm{C}$ for $480 \mathrm{~h}$ demonstrated that the pathogen can survive for a long period (Fig. 2A). Populations declined to levels below $1 \mathrm{ppg}$ of soil when temperatures were maintained at $38^{\circ} \mathrm{C}$ for more than $288 \mathrm{~h}$. After $96 \mathrm{~h}$ of exposure at $41^{\circ} \mathrm{C}$ or $48 \mathrm{~h}$ at $44^{\circ} \mathrm{C}$, no propagules were recovered from the soil. Exposure at $47^{\circ} \mathrm{C}$ reduced the populations to residual levels after $4 \mathrm{~h}$. The decline in survival of the chlamydospores of $P$. nicotianae in soil exposed to constant temperatures above $38^{\circ} \mathrm{C}$ for 2 to $480 \mathrm{~h}$ was determined by

$$
\ln (\mathrm{ppg}+1)=6.2 e^{(-0.00759 \times \text { time }-0.0138 \times \text { temperature })}
$$

The coefficient of determination $\left(R_{\text {adj }}^{2}\right)$ was 0.6773 .

Generally, the use of the tomato seedling assay provided results similar to the soil dilution plating procedure when residual inoculum levels were greater than $0.1 \mathrm{ppg}$ of soil (Fig. 2B). Baiting the soil with seedlings allowed detection of the fungus in two cases that were not detected by soil plating, but failed to detect the pathogen in three other instances that were detected by the plating procedure. All tomato seedlings were colonized by $P$. nicotianae when more than $50 \mathrm{ppg}$ of soil was recovered in the soil dilution plates with PARP; in one case, $100 \%$ infection was observed when 10 ppg of soil was recovered.
The effect of cabbage amendments on the thermal inactivation of chlamydospores. Addition of dried, ground cabbage leaves changed the response of chlamydospores to heat (Fig. 3). As concentration of cabbage increased, thermal inactivation of chlamydospores also increased. Thus, less time was required to inactivate chlamydospores in cabbage-amended soil.

At $35^{\circ} \mathrm{C}$, chlamydospores survived in the soil for $480 \mathrm{~h}$ when no cabbage amendment was present (Fig. 3A). The addition of $0.125 \%$ cabbage to the soil reduced the population to residual levels after $192 \mathrm{~h}$ (Fig. 3B). Ninety-six hours was required with $0.25 \%$ cabbage to reduce population counts below $1 \mathrm{ppg}$ of soil (Fig. 3C); similar population reductions were attained after $48 \mathrm{~h}$ when $0.5 \%$ cabbage was added to the soil (Fig. 3D). A similar
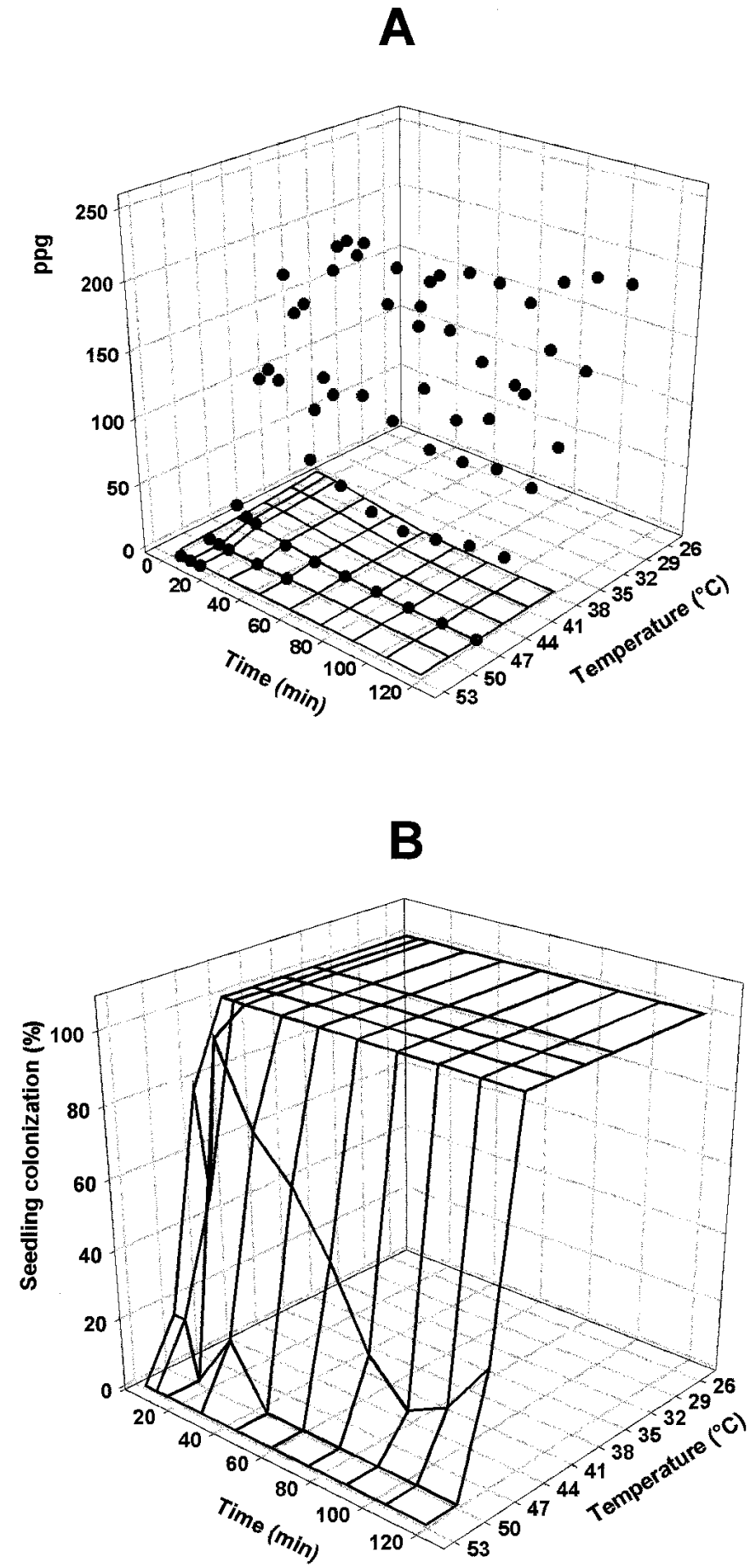

Fig. 1. Effect of temperature $\left(35\right.$ to $53^{\circ} \mathrm{C}$ ) and time (5 to $120 \mathrm{~min}$ ) on the survival of chlamydospores of Phytophthora nicotianae. A, Propagules per gram of soil (ppg) detected on a selective medium. B, Percentage of tomato seedling baits colonized by the pathogen. 
trend in population reduction was obtained with the other two temperatures. The decline in survival of the chlamydospores of $P$. nicotianae in soil amended with cabbage residue and exposed to constant temperature was best described by the linear-power model (Table 1).

Detection of survival of $P$. nicotianae with tomato seedlings as baits followed similar trends as those observed by the soil dilution plating procedure (Figs. 3 and 4). As the number of propagules recovered in the soil plates decreased from 500 to $100 \mathrm{ppg}$ of soil, the percentage of colonized seedlings was relatively constant. Further decreases in the propagule counts were generally reflected in a decrease in the percentage of colonized seedlings. Of the
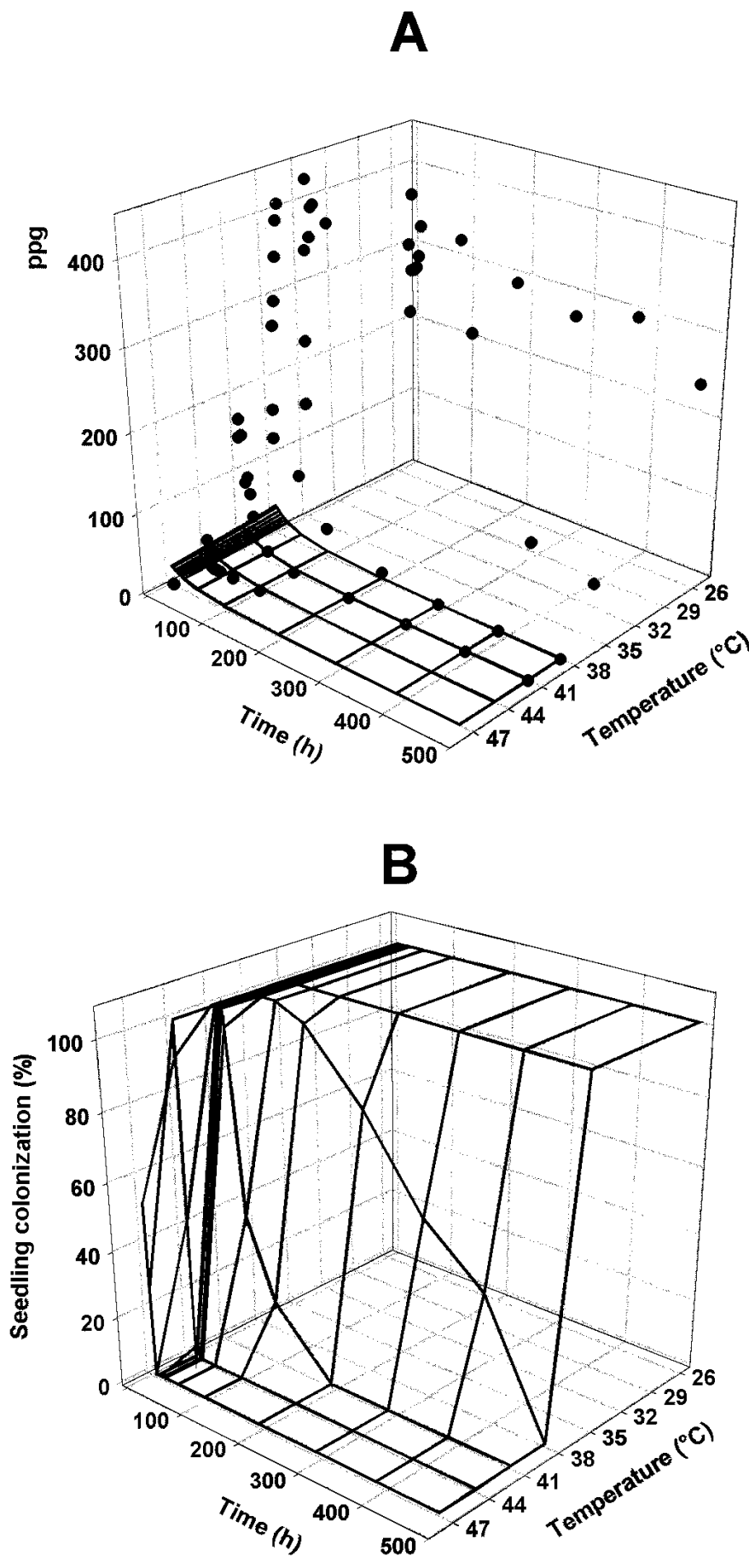

Fig. 2. Effect of temperature $\left(35\right.$ to $53^{\circ} \mathrm{C}$ ) and time ( 2 to $480 \mathrm{~h}$ ) on the survival of chlamydospores of Phytophthora nicotianae. A, Propagules per gram of soil (ppg) detected on a selective medium. B, Percentage of tomato seedling baits colonized by the pathogen.
41 cases in which no propagules were detected by the soil dilution plating procedure, survival of the pathogen was detected in 17 cases by the baiting technique.

The effect of cycling temperatures and cabbage amendments on the thermal inactivation of chlamydospores. Generally, the use of pulsing temperatures increased the time required to inactivate the chlamydospores of $P$. nicotianae in comparison with the constant temperature treatment (Figs. 3 and 5A and B). After 24 days at $35^{\circ} \mathrm{C}$ for $8 \mathrm{~h} /$ day, $40 \%$ of the initial infestation level of spores (500 chlamydospores per $\mathrm{g}$ of soil) was recovered from the nonamended soil in the selective medium. Addition of $0.125 \%$ cabbage to the soil reduced the population to levels below $10 \%$ after 18 days. The effect of cabbage was evident from the beginning of the experiment. A similar trend in population reduction was obtained with the other two temperature regimes.

Exposure to temperature regimes simulating optimum solarization periods reduced the populations to very low levels (Figs. 5A and B). After $5 \mathrm{~h} /$ day at $44^{\circ} \mathrm{C}$ for 15 days the population was reduced to $0.4 \mathrm{ppg}$ of soil. Cabbage amendment reduced populations to the same levels after 6 days. Three days of exposure at $47^{\circ} \mathrm{C}$ for $3 \mathrm{~h} /$ day was required to reduce populations to levels below $1 \mathrm{ppg}$ of soil; cabbage amendment populations were reduced to levels below 1 ppg of soil after 2 days. Populations were reduced to levels below detection only at the two highest temperature regimes $\left(44^{\circ} \mathrm{C}\right.$ for $5 \mathrm{~h} /$ day and $47^{\circ} \mathrm{C}$ for $3 \mathrm{~h} /$ day) after 9 days of treatment. Soil amendment with cabbage had a greater impact at lower temperatures, because the heat alone was not sufficient to inactivate the chlamydospores.

The reduction in survival of $P$. nicotianae was modeled using linear regression. The model selected for the comparisons among temperature regimes and cabbage amendment was $1 \mathrm{n}(Y+1)=a+$ $b \times X$, in which $Y$ is the number of propagules recovered per gram of soil and $X$ is the number of days of exposure to the temperature regime. A lack of fit of the model to the data was observed at $35^{\circ} \mathrm{C}$, regardless of the cabbage amendment (Table 2).

The plant disease assay verifying the pathogenicity of the surviving populations of $P$. nicotianae indicated that temperature regimes below $44^{\circ} \mathrm{C}$ for $5 \mathrm{~h} /$ day did not reduce the colonization of the tomato seedling root systems (Fig. $5 \mathrm{C}$ and D). At $44^{\circ} \mathrm{C}$ for $5 \mathrm{~h}$, colonization was reduced in the soil amended with cabbage after 3 days. After 3 days of heat treatment at $47^{\circ} \mathrm{C}$ for $3 \mathrm{~h} /$ day, no colonization of seedlings was observed. Mortality of the seedlings was observed in the lower temperature regimes (Fig. 5E and F); however, when the soil was treated at $44^{\circ} \mathrm{C}$ for $5 \mathrm{~h}$ /day, no seedlings died, except after 2 or 3 days in soil amended with cabbage. No seedlings died when the soil was heated to $47^{\circ} \mathrm{C}$ for $3 \mathrm{~h} / \mathrm{day}$.

\section{DISCUSSION}

In the present study, the effects of time and temperature on the survival of $P$. nicotianae were evaluated over a series of temperatures and times $\left(35\right.$ to $53^{\circ} \mathrm{C}$ for 5 to $120 \mathrm{~min}$ and 35 to $47^{\circ} \mathrm{C}$ for 2 to $480 \mathrm{~h}$ ), in which a response surface approach allowed the simultaneous analysis of the effects of both time and temperature on the survival of the pathogen. The models that best described survival of $P$. nicotianae were linear-exponential or exponential.

The analysis of the effect of temperature regimes on the survival of $P$. nicotianae indicates that a single model is inadequate to describe the changes in survival over time as temperature increased. At the base temperature regime of $35^{\circ} \mathrm{C}$ for $8 \mathrm{~h} /$ day, none of the models accurately described survival, which was affected little by the temperature regime. As temperature increased, the change in survival was best explained by an exponential model, a model of square root of either time or survival, a logarithmic model of time, and a model of the reciprocal of time. The changes in spore survival that resulted in these models may have occurred as constant numbers of spores died per unit time at lower temperatures, constant proportion of the population was killed per unit time 
at intermediate temperatures, and larger proportions of populations were inactivated early during exposure to the highest temperature.

The use of tomato seedlings as baits to detect survival of $P$. nicotianae in the treated soil demonstrated that this method can be as sensitive as the soil dilution plating procedure, except when residual populations of less than $1 \mathrm{ppg}$ of soil occur. The rationale for using the baiting test was that heat treatment at temperatures that did not eliminate the pathogen from the soil could have affected the ability of the surviving population to infect and colonize a susceptible host or to germinate in the presence of an external stimulus, such as root exudates. However,

A

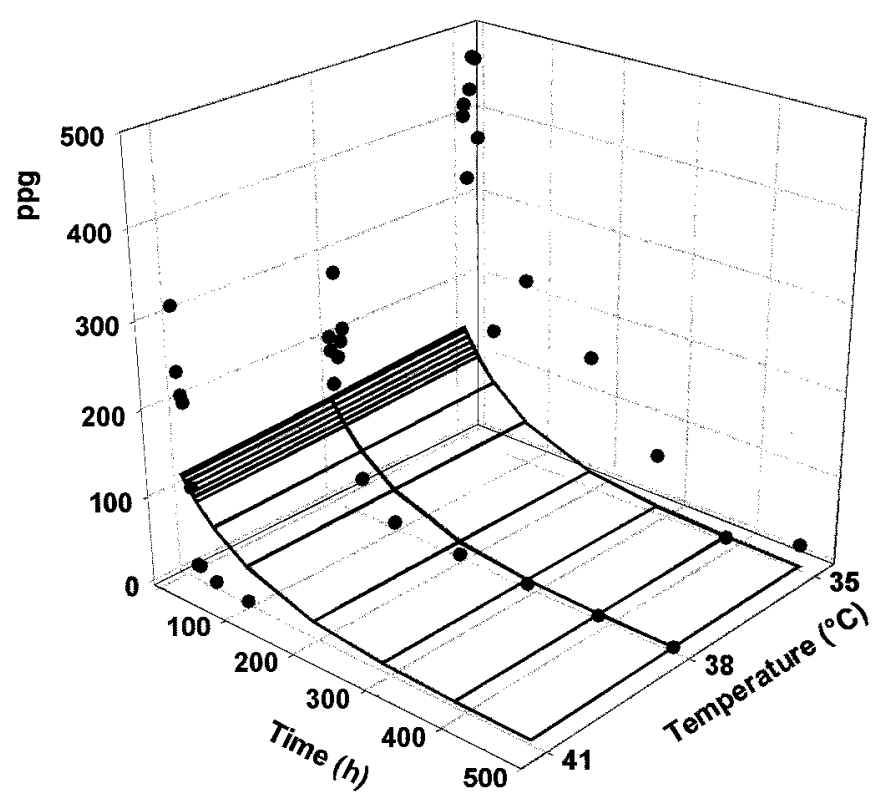

C

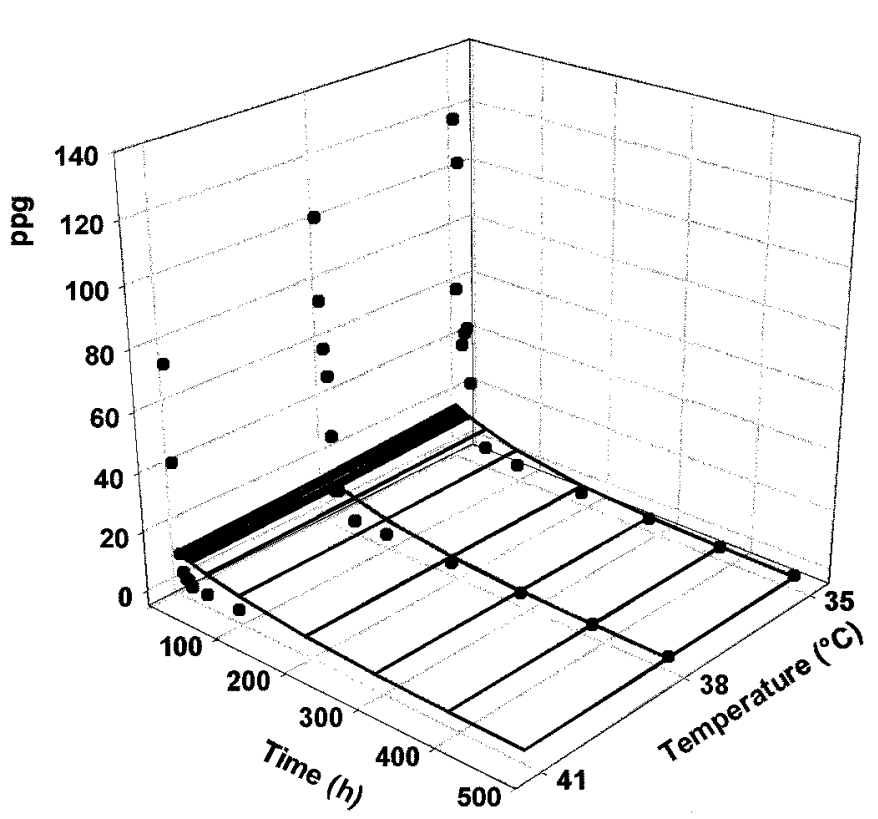

it is clear from these tests that when $P$. nicotianae is present in the soil, even at residual levels, infection of a tomato seedling can occur. The baiting technique has several disadvantages: the population of the pathogen is not quantified, extensive amounts of time and space may be required to grow the seedlings and incubate the baited soil, and the soil samples may be cross contaminated due to handling procedures.

Amending infested soils with dried, ground cabbage leaves and exposing it to heat treatment generally reduced survival of $P$. nicotianae in the present study. The effectiveness of cabbage amendment can be observed in two ways: (i) at a given tempera-

B

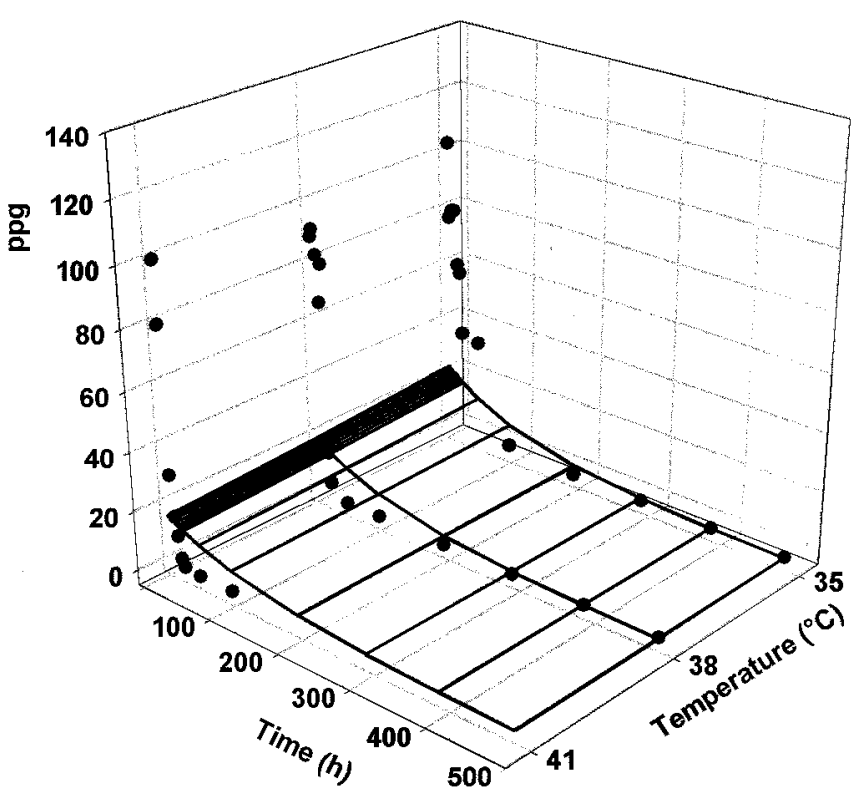

D

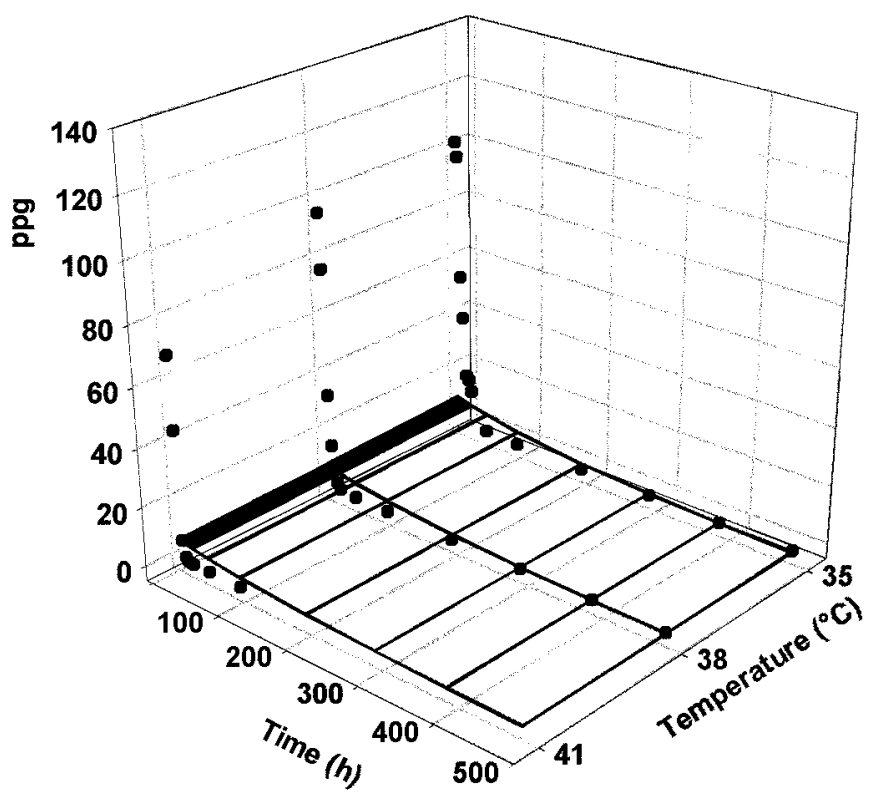

Fig. 3. Effect of temperature, cabbage amendment, and time on the survival of chlamydospores of Phytophthora nicotianae. Propagules per gram of soil (ppg) detected on a selective medium after heat treatment in soil amended with $\mathbf{A}, 0 \%$ cabbage; $\mathbf{B}, 0.125 \%$ cabbage; $\mathbf{C}, 0.25 \%$ cabbage; and $\mathbf{D}, 0.5 \%$ cabbage. 
TABLE 1. Models of the thermal inactivation of chlamydospores of Phytophthora nicotianae as a function of constant temperature between 35 and $41^{\circ} \mathrm{C}$, time of exposure from 2 to $480 \mathrm{~h}$, and cabbage amendment concentrations

\begin{tabular}{llc}
\hline Cabbage \% & \multicolumn{1}{c}{ Equation $^{\mathrm{z}}$} & $R^{2}$ \\
\hline 0 & $\ln (\mathrm{ppg}+1)=(6.2-0.0141 \times$ Time $) e^{-0.0063 \times \text { Temp } \mathrm{a}}$ & 0.5062 \\
0.125 & $\ln (\mathrm{ppg}+1)=(6.2-0.0181 \times$ Time $) e^{-0.0191 \times \text { Temp } \mathrm{b}}$ & 0.5474 \\
0.25 & $\ln (\mathrm{ppg}+1)=(6.2-0.0183 \times$ Time $) e^{-0.0232 \times \text { Temp } \mathrm{b}}$ & 0.6124 \\
0.5 & $\ln (\mathrm{ppg}+1)=(6.2-0.0187 \times$ Time $) e^{-0.0282 \times \text { Temp } \mathrm{c}}$ & 0.6928 \\
\hline
\end{tabular}

${ }^{\mathrm{z}}$ Equations followed by the same letter do not differ statistically $(P \leq 0.05)$; ppg = propagules per gram of soil.
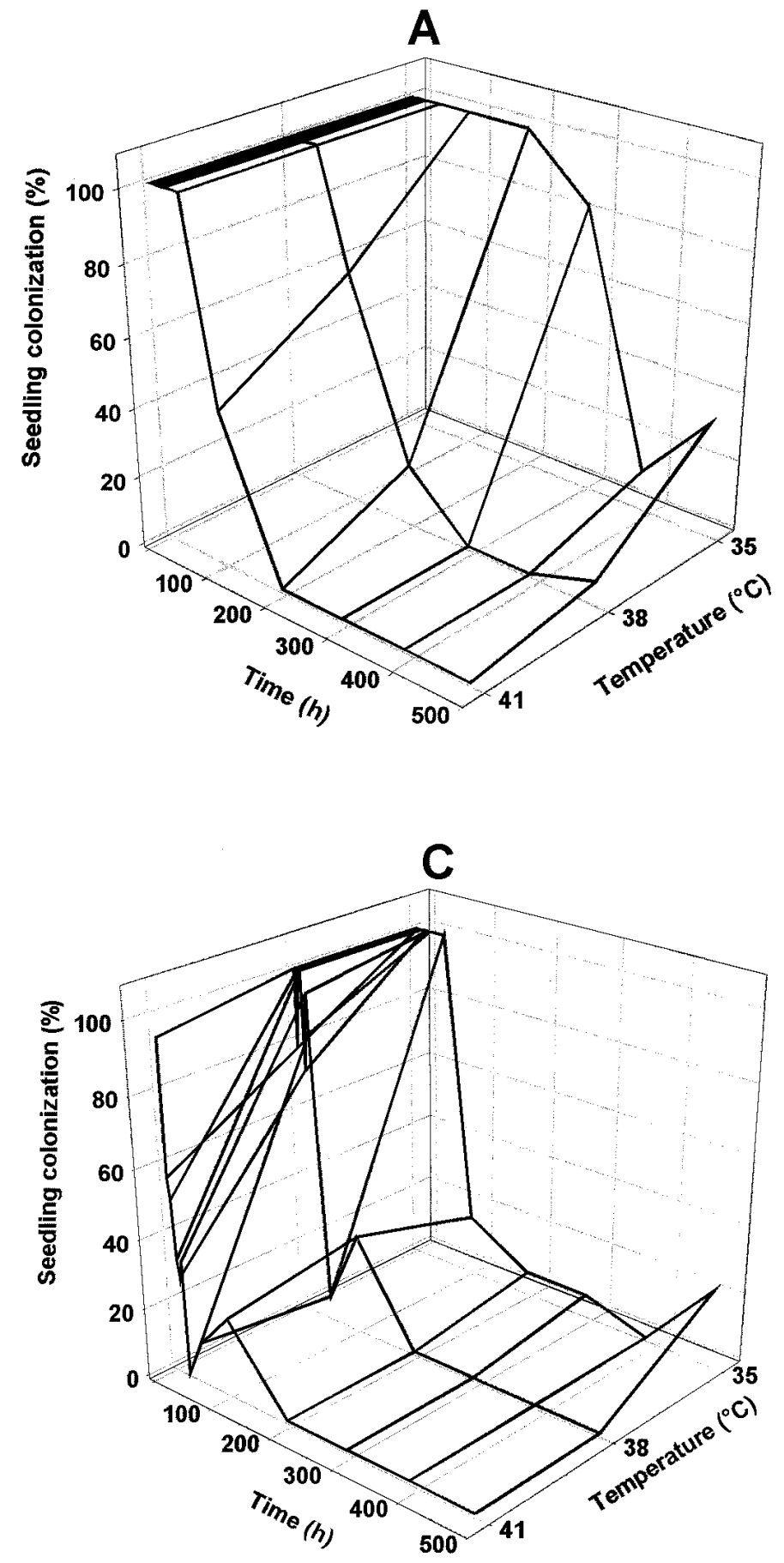

ture, less time is required to achieve the same reduction in population as cabbage concentration increases; and (ii) with increasing concentrations of cabbage amendment, lower temperatures are required to achieve the same reduction in populations of the pathogen. In soil amended with $0.5 \%$ cabbage, populations of $P$. nicotianae were eliminated after $24 \mathrm{~h}$ at $41^{\circ} \mathrm{C}, 48 \mathrm{~h}$ at $38^{\circ} \mathrm{C}$, and $96 \mathrm{~h}$ at $35^{\circ} \mathrm{C}$. These findings contrast with the results obtained in field work where no additional reductions in populations of $P$. nicotianae were achieved with cabbage amendments (8). Such a contrast can be explained by the different environments and procedures used in the two experiments. Cabbage was air dried and ground to a fine powder and uniformly mixed with the soil for the thermal inactivation tests. The field trials were performed with
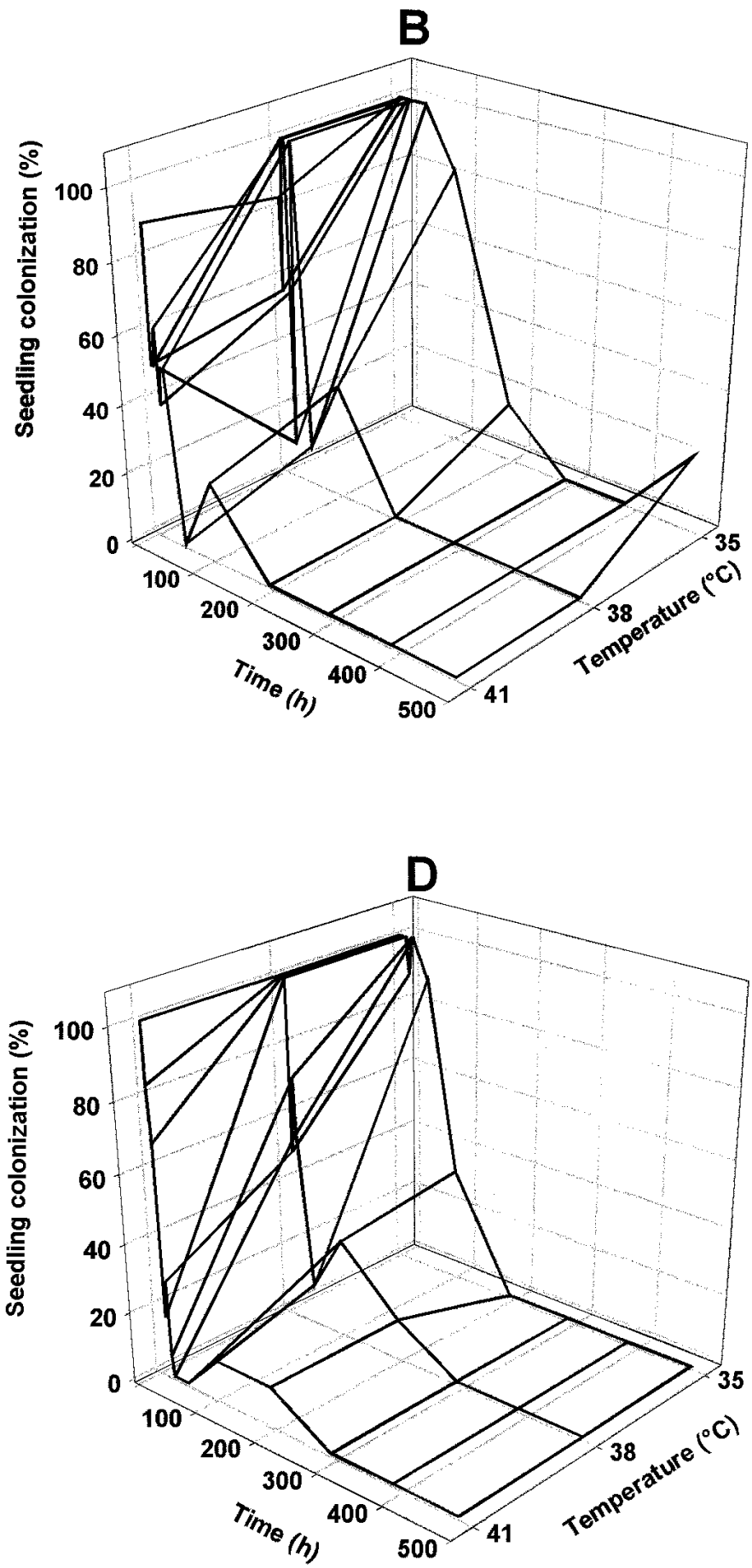

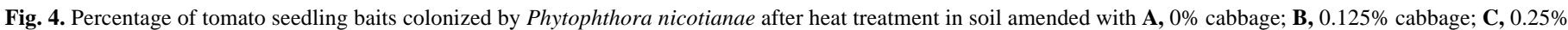
cabbage; and $\mathbf{D}, 0.5 \%$ cabbage. 
coarsely chopped cabbage, dried on the soil beds, and disked into the soil, resulting in large pieces of cabbage unevenly distributed in the soil that may have prevented a uniform release of volatile compounds upon heating.
The use of cabbage amendment without additional soil heating was effective for the control of Aphanomyces euteiches (14) but provided inconsistent control of $F$. oxysporum $\mathrm{f}$. sp. conglutinans $(22,23)$. Heating cabbage-amended soils induces the volatilization

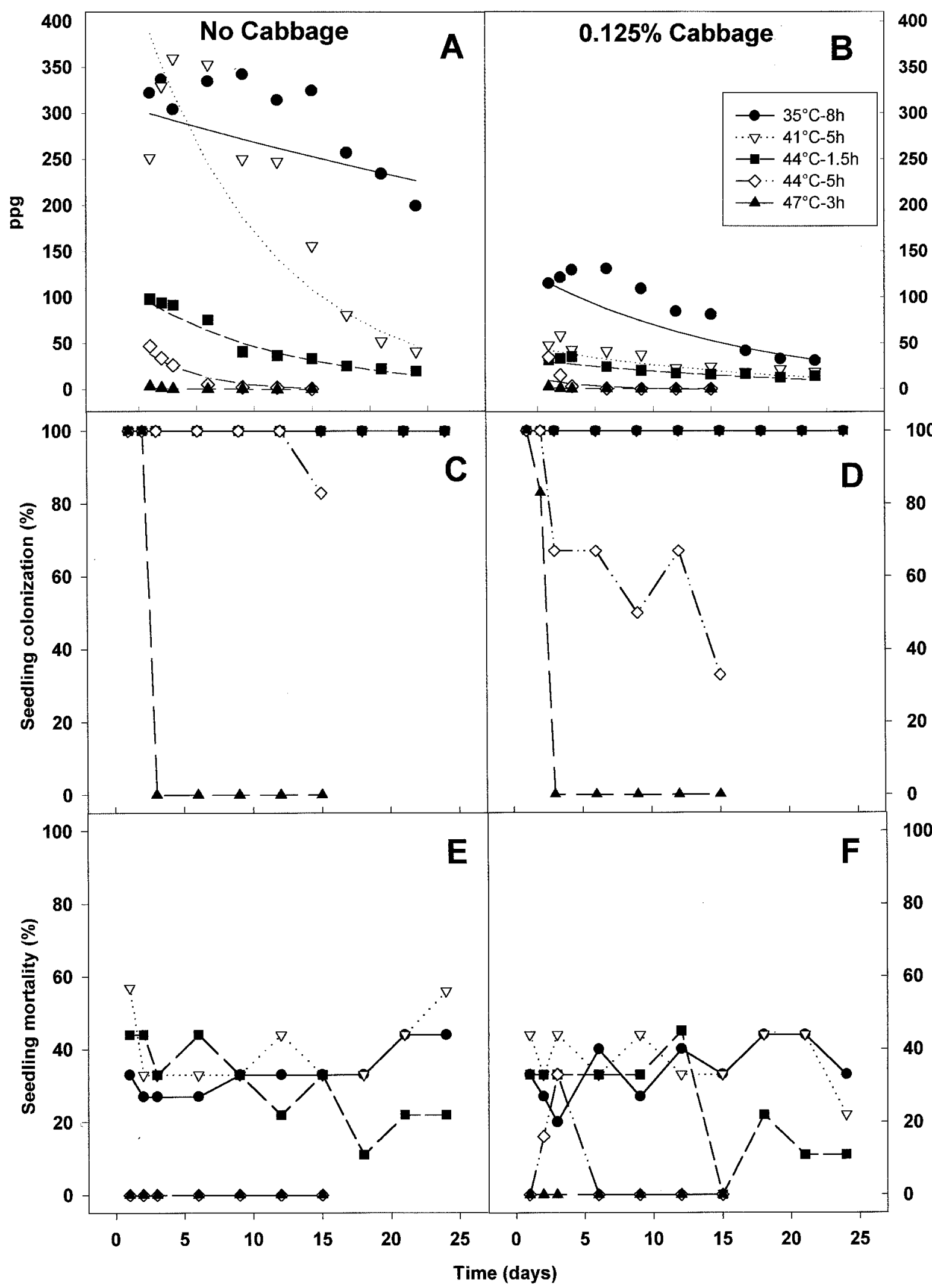

Fig. 5. The effect of temperature regime, cabbage amendment, and time on the survival of chlamydospores of Phytophthora nicotianae. Temperature regimes that simulated solarization consisted of temperatures increased daily to $35^{\circ} \mathrm{C}(\bullet), 41^{\circ} \mathrm{C}(\nabla), 44^{\circ} \mathrm{C}(\bullet), 44^{\circ} \mathrm{C}(\diamond)$, or $47^{\circ} \mathrm{C}(\boldsymbol{\Delta})$ for $8,5,1.5,5$, or $3 \mathrm{~h}$, respectively; the remainder of each day was maintained at $25^{\circ} \mathbf{C}$. A and B, Propagules per gram (ppg) of soil detected on a selective medium. C and D, Percentage of tomato seedlings colonized by P. nicotianae after 1 month growing in infested soil. $\mathbf{E}$ and $\mathbf{F}$, Percentage of tomato seedling mortality after incubation for 1 month in soil amended with cabbage and infested with P. nicotianae. 
of certain soil volatile compounds, such as methanol, isothiocyanates, and aldehydes, which could be directly correlated to the inactivation of the spores of Pythium ultimum and sclerotia of Sclerotium rolfsii (10). The effect of cabbage amendment is directly proportional to its concentration in the soil (23). Increasing the concentration of cabbage from 0.25 to $2 \%$ reduced the population of $F$. oxysporum f. sp. conglutinans to undetectable levels in 12 days instead of the 30 days required at the lower concentration. Other crucifers, such as kale (B. oleracea var. viridis) and mustard (B. nigra) were also effective for the control of $F$. oxysporum f. sp. conglutinans. Another factor that may determine the effectiveness of the crucifer amendment is the concentration of glucosinolates present in the crop (15).

One major benefit of the use of intermittent heat in thermal inactivation studies is the provision of estimates of the effectiveness of soil solarization to control plant pathogens. However, cycling temperatures have not been employed routinely, possibly due to the compounded difficulties of establishing appropriate temperature regimes, the daily requirement of adjusting each temperature, and the longer time required to reach desirable control of the organism under study.

Wicks (26) analyzed the effect of intermittent heat on the survival of mycelium of $P$. cambivora. None of the isolates tested survived after 1 day at a regime of $45^{\circ} \mathrm{C}$ for $6 \mathrm{~h}$ /day and $20^{\circ} \mathrm{C}$ for $18 \mathrm{~h} /$ day. The response of the isolates was variable and inconclusive at 40 and $35^{\circ} \mathrm{C}$ for $6 \mathrm{~h} /$ day for 4 days. However, mycelium is not the most likely survival structure of $P$. cambivora in the soil.

Tjamos and Fravel (25) evaluated intermittent heat on the survival of a suspension of microsclerotia of Verticillium dahliae over 4 days. After 4 days at the highest temperature regime, less than $1 \%$ of the sclerotia germinated. In their study the use of sclerotium suspensions in water negated the insulating effect of air pockets in the soil, and the duration of the high temperature in each regime was longer than that which would normally occur under field conditions.

A more comprehensive study was done by Porter and Merriman (20) with several soilborne plant pathogens. Survival of each pathogen depended on the heat sensitivity of the type of propagule being evaluated. For example, $V$. dahliae did not survive for 15 days when the high temperature was above $40^{\circ} \mathrm{C}$; in contrast, Pythium irregulare was recovered at $5 \times 10^{4} \mathrm{ppg}$ of soil at $50^{\circ} \mathrm{C}$ at the end of the experiment.

Gamliel and Stapleton (10) selected two temperature regimes similar to those found in the San Joaquin Valley in California to evaluate the effectiveness of the regimes and cabbage amendment on the control of Pythium ultimum and S. rolfsii. Both pathogens were eliminated after 4 days in the cabbage-amended soil at tem-

TABLE 2. Regression coefficients of the linear regressions of temperature regimes and survival of chlamydospores of Phytophthora nicotianae ${ }^{\mathrm{x}}$

\begin{tabular}{lccccc}
\hline & & \multicolumn{2}{c}{ Parameters } & & \\
\cline { 3 - 4 } Temp $\left({ }^{\circ} \mathrm{C}\right)^{\mathrm{y}}$ & Cabbage $\%$ & Slope & Intercept & $R^{2}$ & $P$ value \\
\hline $35(8)$ & 0 & -0.01203 & 5.717 & 0.0267 & 0.062 \\
$35(8)$ & 0.125 & -0.05508 & 4.808 & 0.2800 & 0.001 \\
$41(5)$ & 0 & -0.09034 & 6.049 & 0.6679 & 0.001 \\
$41(5)$ & 0.125 & -0.05091 & 3.812 & 0.2195 & 0.001 \\
$44(1.5)$ & 0 & -0.07680 & 4.631 & 0.7264 & 0.001 \\
$44(1.5)$ & 0.125 & -0.04426 & 3.454 & 0.2856 & 0.001 \\
$44(5)$ & 0 & -0.26132 & 3.886 & 0.8684 & 0.001 \\
$44(5)$ & 0.125 & -0.21618 & 2.531 & 0.5631 & 0.001 \\
$47(3)$ & 0 & -0.05692 & 0.718 & 0.2422 & 0.001 \\
$47(3)$ & 0.125 & -0.04026 & 0.455 & 0.2272 & 0.001 \\
\hline
\end{tabular}

$\times$ The model used for the analysis was $\ln (\mathrm{ppg}+1)=a+b \times$ days.

y Temperature regimes that simulated solarization consisted of temperatures increased daily to $35,41,44,44$, and $47^{\circ} \mathrm{C}$ for (length of time in parenthesis in hours) $8,5,1.5,5$, and $3 \mathrm{~h}$, respectively; the remainder of each day was maintained at $25^{\circ} \mathrm{C}$.

${ }^{\mathrm{z}}$ Significance associated to the coefficient of determination $\left(R^{2}\right)$. perature regimes of 38 or $45^{\circ} \mathrm{C}$ for $4 \mathrm{~h} /$ day plus $20 \mathrm{~h}$ at $30^{\circ} \mathrm{C}$; however, propagules of these pathogens could be recovered from the nonamended soil after 4 days at the same temperature regimes.

Comparisons between studies are further complicated due to the difference in length of the experiments, amplitude between low and high temperatures in each regime, and duration of the high temperature. If an in vitro experiment is compared with soil solarization in the field, then the duration of the in vitro study should be similar to the solarization trial and the temperature regimes should simulate those observed during solarization.

In the present study, populations of $P$. nicotianae decreased to residual levels after 15 days only when temperature regimes simulating optimum solarization conditions $\left(47^{\circ} \mathrm{C}\right.$ for $3 \mathrm{~h} /$ day $)$ were used; under these circumstances no infection of tomato seedlings was observed after as little as 3 days of heat treatment. The use of $44^{\circ} \mathrm{C}$ for $5 \mathrm{~h}$ /day reduced populations to levels below 1 ppg of soil. However, colonization of tomato seedlings exposed to this regime was observed throughout the experiment. The use of temperature regimes simulating average field temperature regimes reduced the populations to at least $40 \%$ of the initial infestation level, but all seedlings were colonized at these regimes.

\section{ACKNOWLEDGMENTS}

This research was supported, in part, by the Gadsden County Tomato Growers Association and the U.S. Department of Agriculture specific cooperative agreement 58-6617-4-019, and L. Coelho was supported by CNPq, Conselho Nacional de Pesquisa e Desenvolvimento, Brazil.

\section{LITERATURE CITED}

1. Alfieri, S. A., Jr., Langdon, K. R., Kimbrough, K. R., El-Gholl, N. E., and Wehlburg, C. 1994. Diseases and disorders of plants in Florida. Fla. Dep. Agric. Consum. Serv. Div. Plant Ind. Bull. 14.

2. Benson, D. M. 1978. Thermal inactivation of Phytophthora cinnamomi for control of Fraser Fir root rot. Phytopathology 68:1373-1376.

3. Bigelow, W. D. 1921. The logarithmic nature of thermal death time curves. J. Infect. Dis. 29:528-536.

4. Bigelow, W. D., and Esty, J. R. 1920. The thermal death point in relation to time of typical thermophilic organisms. J. Infect. Dis. 27:602-617.

5. Bollen, G. J. 1985. Lethal temperatures of soil fungi. Pages 191-193 in: Ecology and Management of Soilborne Plant Pathogens. C. A. Parker, A. D. Rovira, K. J. Moore, P. T. W. Wong, and J. F. Kollmorgen, eds. The American Phytopathological Society, St. Paul, MN.

6. Chellemi, D. O., Olson, S. M., and Mitchell, D. J. 1994. Effects of soil solarization and fumigation on survival of soilborne pathogens of tomato in northern Florida. Plant Dis. 78:1167-1172.

7. Coelho, L. 1997. Reduction of populations of Phytophthora spp. with soil solarization under field conditions and thermal inactivation of Phytophthora nicotianae. Ph.D. diss. University of Florida, Gainesville.

8. Coelho, L., Chellemi, D. O., and Mitchell, D. J. 1999. Efficacy of solarization and cabbage amendment for the control of Phytophthora spp. in North Florida. Plant Dis. 83:293-299.

9. Erwin, D. C., and Ribeiro, O. K. 1996. Phytophthora Diseases Worldwide. The American Phytopathological Society, St. Paul, MN.

10. Gamliel, A., and Stapleton, J. J. 1993. Characterization of antifungal volatile compounds evolved from solarized soil amended with cabbage residues. Phytopathology 83:899-905.

11. Gamliel, A., and Stapleton, J. J. 1993. Effect of chicken compost or ammonium phosphate and solarization on pathogen control, rhizosphere microorganisms, and lettuce growth. Plant Dis. 77:886-891.

12. Grooshevoy, S. E., Khudyna, I. P., and Popova, A. A. 1941. Methods for disinfecting seed-bed soil by natural sources of heat. Rev. Appl. Mycol. 20:87-88.

13. Juarez-Palacios, C., Felix-Gastelum, R., Wakeman, R. J., Paplomatas, E. J., and DeVay, J. E. 1991. Thermal sensitivity of three species of Phytophthora and the effect of soil solarization on their survival. Plant Dis. 75:1160-1164.

14. Lewis, J. A., and Papavizas, G. C. 1971. Effect of sulfur-containing volatile compounds and vapors from cabbage decomposition on Aphanomyces euteiches. Phytopathology 61:208-214.

15. Mayton, H. S., Olivier, C., Vaughn, S. F., and Loria, R. 1996. Correlation of fungicidal activity of Brassica species with allyl isothiocyanate production in macerated leaf tissue. Phytopathology $86: 267-271$ 
16. McGovern, R. J., Jones, J. P., Mitchell, D. J., Pluim, R. A., and Gilreath, P. R. 1993. Severe outbreak of Phytophthora blight and fruit rot of cucurbits in Florida. (Abstr.) Phytopathology 83(suppl.):S1388.

17. Mitchell, D. J., and Kannwischer-Mitchell, M. E. 1992. Phytophthora. Pages 31-38 in: Methods for Research on Soilborne Phytopathogenic Fungi. L. L. Singleton, J. D. Mihail, and C. M. Rush, eds. The American Phytopathological Society, St. Paul, MN.

18. Myers, D. F., Campell, R. N., and Greathead, A. S. 1983. Thermal inactivation of Plasmodiophora brassicae Woron. and its attempted control by solarization in the Salinas Valley of California. Crop Prot. 2:325-333.

19. Porter, I. J. 1991. Factors which influence the effectiveness of solarization for control of soilborne fungal pathogens in South Eastern Australia. Ph.D. diss. La Trobe University, Bundoora, Victoria, Australia.

20. Porter, I. J., and Merriman, P. R. 1983. Effects of solarization of soil on nematode and fungal pathogens at two sites in Victoria. Soil Biol. Biochem. 15:39-44.
21. Pullman, G. S., DeVay, J. E., and Garber, R. H. 1981. Soil solarization and thermal death: A logarithmic relationship between time and temperature for four soilborne plant pathogens. Phytopathology 71:959-964.

22. Ramirez-Villapudua, J., and Munnecke, D. E. 1987. Control of cabbage yellows (Fusarium oxysporum f. sp. conglutinans) by solar heating of field soils amended with dry cabbage residues. Plant Dis. 71:217-221.

23. Ramirez-Villapudua, J., and Munnecke, D. E. 1988. Effect of solar heating and soil amendments of cruciferous residues on Fusarium oxysporum f. sp. conglutinans and other organisms. Phytopathology 78:289-295.

24. Smith, J. H. 1923. The killing of Botrytis cinerea by heat, with a note on the determination of temperature coefficients. Ann. Appl. Biol. 10:335-347.

25. Tjamos, E. C., and Fravel, D. R. 1995. Detrimental effects of sublethal heating and Talaromyces flavus on microsclerotia of Verticillium dahliae. Phytopathology 85:388-392.

26. Wicks, T. J. 1988. Effect of solarization on the control of Phytophthora cambivora in almond and cherry. Aust. J. Exp. Agric. 28:539-545. 